\title{
Direct democracy: obstacle to reform?
}

\author{
Gebhard Kirchgässner
}

\begin{abstract}
Swiss direct democracy is often accused of being an obstacle to reforms, with the strong influence of interest groups being the reason. Actually, the referendum has a retarding effect: it implies a status quo bias. On the other hand, the initiative has an accelerating effect. The influence of interest groups is hardly larger in direct compared to representative democratic systems. Thus, it is highly questionable whether the abolition of Switzerland's direct democracy (at the federal level) would - in the long-run — really lead to political decisions which are more open to reforms.
\end{abstract}

Keywords Direct democracy · Referendum · Initiative ·

Political and economic reform

\section{JEL Classification C53}

\section{Introduction}

Switzerland has the most extensive direct democratic system all over the world. All levels, the local, the cantonal as well as the federal one, know the initiative and the referendum. Any change of a constitution, be it the federal or a cantonal one, has to be approved by the people. Moreover, the frequency of referenda is quite high. Between 1981 and 2006, only at the federal level, there were 223 referenda and

Earlier versions of this paper have been presented at the Annual Meeting of the European Group of Public Administration (EGPA), Bern, September 2005, and at the Annual Meeting of the European Public Choice Society, Turku, April 2006. Final Version, February 2008.

G. Kirchgässner $(\bowtie)$

University of St. Gallen, Swiss Institute of International Economics and Applied Economic Research, CESifo, and Leopoldina, SIAW-HSG, Bodanstrasse 8, 9000 St. Gallen, Switzerland e-mail: Gebhard.Kirchgaessner@unisg.ch 
initiatives to decide on. Thus, there is no other country where the citizens can participate to such an extent in political processes.

However, in the last 15 years, this system of direct popular rights, especially the optional referendum, has quite often been accused of being an obstacle to reforms. ${ }^{1}$ In 1990, Borner et al. (p. 19) wrote:

The direct democracy which gives well organised interest groups the permanent possibility to delay or even prevent a coherent strategy is, as the core characteristic of our institutional system, the main reason for the insufficient international orientation of Swiss politics. A real improvement of the long-run adaptability, therefore, demands a modification of the direct democratic instruments.

More recently, Borner wrote:

The decisive effect of the optional referendum is that this mechanism makes any major change of the institutional framework more difficult for the government and the parliament... In Switzerland, comprehensive political or economic changes are exceptions. ${ }^{2}$

Even more pronounced is Wittmann (1998, p. 206f): ${ }^{3}$

... direct democracy quite generally and the referendum especially will-in the long-run-ruin the Swiss economy because they impede market oriented reforms. The direct democracy is on the way to endanger and destroy Switzerland.

Consequently, he demands that direct popular rights should be cut back or even totally abandoned

Switzerland has to debark from direct democracy and turn to a parliamentary democracy, as it is in other countries. (Ibid., p. 233.)

The main argument of these authors is the bad economic performance of Switzerland between 1990 and 2004; in these 15 years it had-on average - the lowest economic growth rate of all OECD countries. The main reason for this bad performance is seen in the lack of economic reforms which is due to the retarding effect of the (optional) referendum.

There is no doubt that Switzerland did perform quite badly with respect to this indicator during this period. Moreover, in the last decades, liberalisation of former strongly regulated markets has gone much less far than in the European Union. This holds, for example, for the electricity market or for postal services. On the other hand, with respect to other economic indicators like GDP per capita, unemployment or international competitiveness, the Swiss economy performs quite well. The Swiss labour market, for example, is much less regulated than the ones of its neighbouring

\footnotetext{
1 There has also been criticism before, like by Imboden (1964) or German (1975).

2 Borner, Direkte Demokratie - letzter Schweizer Mythos, Neue Zürcher Zeitung No. 1 of January 3/4, 1997, pp. B9f.

3 See also Wittmann (2001).
} 
countries. This might also be an effect of direct democracy, and a major reason for the low unemployment rate. Thus, the picture the Swiss economy presents today is mixed, and positive as well as negative aspects of this picture might be related to the Swiss political system.

Nevertheless, as will be shown below, there is a long list where the people have rejected reform proposals, even if those had a large majority in both chambers of the parliament. Thus, the referendum can increase the 'status quo bias' of political systems. ${ }^{4}$ On the other hand, the initiative enables citizens to put issues on the political agenda which might not (yet) be seen as being relevant by the political representatives. Thus, be it for good or for bad: direct democratic instruments can both retard and accelerate the political process.

Moreover, Switzerland is by far not the only country which is said to have a 'reform-delay' (Reformstau). Its large northern neighbouring country, Germany, for example, suffers at least as deeply from this phenomenon as Switzerland, despite the fact that it has a purely representative system at the federal level and-at least compared to Switzerland or the United States-only rudimentary elements of direct popular rights. Moreover, in 2004, Switzerland managed to pass a major reform of its federal system. In Germany a first attempt for such a reform failed in December 2004, and only a small first step was realised in September 2006, leaving the really pressing questions of the distribution of the finances between the federal and the state levels open to a second round which is going on at the moment. However, even rather optimistic observers do not believe that this reform will go very far. Thus, despite the fact that due to its "joint decision trap" ${ }^{5}$ the demand for a reform is much stronger, the whole package will together be much more limited than the Swiss reform. Similar observations could be made with respect to the liberalisation of labour markets. Thus, the available international—admittedly casual—evidence is at least not unambiguous.

In the following, first the retardation effect of the referendum is discussed (Sect. 2 ). It is also considered why this status quo bias might be beneficial. Then we turn to the accelerating effect of the initiative (Sect. 3). As the influence of interest groups in the political system is often seen as the main reason why reforms are delayed, in Sect. 4, we discuss this impact in direct and representative systems. Finally, in Sect. 5, we discuss some of the possible changes which might result if Switzerland were to abolish its direct democracy (at least at the federal level). It is highly questionable whether such a change - in the long-run-really would lead to 'better' political decisions, and/or to decisions which would be more open to reforms.

\footnotetext{
4 The status quo bias in personal decision making has first been demonstrated by Samuelson and Zeckhauser (1988). Fernandez and Rodrik (1991) show that this bias can prevent political reforms, even if they would be efficient from an economic point of view, when there would be more winner than losers, and that this may occur even if neither risk aversion, nor irrationality, nor hysteresis due to sunk costs play a role.

5 See for this Scharpf (1988).
} 


\section{The retarding effect of the referendum}

There is a long and rather impressive list of referenda which delayed reforms or even rendered them impossible. Let us just consider a few rather prominent ones: ${ }^{6}$

- On February 1, 1959, the male voters rejected (for the last time) the women's right to vote. It was accepted 12 years later in the referendum of February 1, 1971.

- On March 2, 1975, an amendment to the constitution which should provide a new basis for stabilisation policy ('Konjunkturartikel') was rejected. A modified version was accepted on February 27, 1978.

- On December 5, 1976, the introduction of the $40 \mathrm{~h}$ working-week was rejected.

- On June 12, 1977, the switch from a sales to a value added tax was rejected. On May 20, 1979, it was rejected once more. Finally, on November 28, 1993, it was accepted.

- On December 6, 1992, the citizens rejected joining the European Economic Area (EEA).

- On December 1, 1996, the revision of the labour law was rejected. A modified version was accepted on November 29, 1998.

- On September 22, 2002, a new law (de-)regulating the electricity market was rejected.

- On May 16, 2004, a major reform of the federal income tax was rejected.

These (and other) examples indicate that it can be difficult to introduce reforms in a direct democratic system. However, as its neighbouring countries, Germany and France, show, it might also be difficult to make reforms in purely parliamentary systems. Direct democratic rights might be an impediment to reforms, but they are certainly not the only ones. Not different from the situation in representative systems, the last 10 years have shown that reforms are possible if there is some economic pressure. ${ }^{7}$

Moreover, at least in some cases, the main reason for the delay was not that the majority of the citizens was principally against a reform but that the parliament made a 'package-deal': When the new labour law was to be decided on in 1996, the parliament added a new regulation concerning business hours on Sundays to the original proposal of the government. As the results of previous votes showed, this new regulation did not find the support of a majority of voters. The second attempt which skipped this addition and nearly went back to the regulation the government had originally proposed, got a clear majority in 1998. In 2004, the-hardly disputed - change in family taxation was combined with new subsidies for home owners which not only were mostly at the expense of the cantons but had already been rejected in a decision about an initiative five years earlier.

\footnotetext{
${ }^{6}$ As indicated by the statements above, in the political discussion it is mostly the optional referendum which is made responsible for the delay of reforms. However, in six of the eight examples mentioned below it was a mandatory referendum. Thus, in this respect the mandatory is at least as important as the optional referendum.

7 See for this also Gagales et al. (2005).
} 
The most interesting case is probably the change from the sales-tax to the valueadded tax. In first attempts, these changes were combined with a significant rise of the tax rate. It is not astonishing that the citizens rejected to accept these proposals. In March 1993, the package-deal was broken up and three separate decisions had to be taken: (i) the change of the system, (ii) an increase of the tax rate from $6.2 \%$ to $6.5 \%$, and an additional increase to $7.5 \%$ (to be introduced later) to get additional revenue for the first column of the Swiss old age pension system, which is financed by a pay-as-you-go system. The people accepted all three proposals. It can be taken for granted that the proposals would have been rejected if they had again been combined within a package. Nevertheless, as the referendum on the tax reform in May 2004 shows, despite this evidence the parliamentarians again and again succumb to the temptation to put a package-deal together in order to get something through that the citizens do not want. In these cases, it is the parliamentary and not the direct-democratic part of the political system which is responsible for the delay of reforms.

There are, of course, other decisions where the voters (and nobody else) were responsible for a delay. Thus, the referendum can aggravate the status quo bias. However, at least as long as this bias is not too strong, it remains open how it should be evaluated. A rejection of a reform can be advantageous in the long-run, if the reform would go into the 'wrong' direction. From the perspective of economic liberalism, this might hold for several of the examples mentioned above, for example for the rejection of the 40-h working-week and probably also for the rejection of the first version of the Konjunkturartikel. On the other hand, the rejection of joining the European Economic Area was certainly an impediment for Switzerland's economic development. And the results are also ambivalent from a political perspective. During the seventies, when social-democratic concerns like the 40-h working-week were rejected, the bourgeois parties benefited from using the direct instruments, as the general public gave more credit to their arguments than the parliament. In the nineties, the opposite situation seemed to exist: The left political side could successfully use the referendum for preventing-at least partlyunwanted reforms. Thus, in different situations the status quo bias helps different political parties or interest groups.

This indicates what—in principle—should be self-evident: the quality of a direct democratic system should not be evaluated on the basis of single, selected decisions or on the current constellation of interests, which might change in the future, but on the expected average quality of all political decisions under different constellations together. As the list above shows, there are examples where referenda prevented decisions which might have been beneficial for Switzerland in the long-run. However, there are also examples of opposite situations. Taking examples can only indicate what can be the case, but this is not sufficient for proving systematic relationships. It can (and does) indicate that both systems have advantages and disadvantages. To reveal which is the better one (and in which respect) demands systematic empirical analyses. The available studies show that at least the economic performance of direct democratic systems is not worse than the one of purely 
representative systems; the results indicate that it is rather better. ${ }^{8}$ Thus, even if there is a delay of reforms, it does not seem to create major economic problems in the long-run.

Nevertheless, due to the referendum, the status quo has at least some advantage compared to new political proposals in the Swiss direct democracy. Insofar, the critics of the direct democracy are right. But it also has to be asked whether such a status quo bias does make sense. Stability of a political system is usually acknowledged as being an advantage. It generates reliability for the plans of private agents which is often said to be a precondition for economic prosperity. ${ }^{9}$ Of course, a system can also be too stable and, therefore, miss necessary innovations. Nevertheless, at least with respect to the mandatory referendum that is relevant for constitutional changes it should be uncontroversial that-ceteris paribus-stability should be an advantage. It is not for nothing that most constitutions demand high quorums for constitutional changes; in bi-cameral purely representative systems it is usually a two third-majority in both chambers. Insofar, one might even argue that the Swiss constitutional status quo is not protected enough, because-given a certain distribution between the cantons - a simple majority of the population is sufficient to change the constitution.

The final question in this respect is whether a reform should be performed at all if the majority of citizens votes against it. The assumption behind such a consideration (and also behind most of the statements which complain about Switzerland's reform deficit) is that the political representatives (and/or some other elites) know better what is good for the society and for the citizens than the latter themselves. In a democracy, such a position is at least not without problems. Taking the (pure) theory of democracy, the median voter should be decisive in a democratic system. There is clear evidence that the outcome of direct democratic systems is closer to the median voter's decision than the outcome of a purely representative system. ${ }^{10}$ Insofar, the retarding effect of the referendum does at least not seem to be too damaging.

\section{The accelerating effect of the initiative}

When discussing the reform ability of the Swiss system of direct democracy, it is not sufficient to consider only the referendum; the initiative has also to be taken into account. While the referendum is the brake, the initiative is the gas pedal of the direct democracy. ${ }^{11}$ This is obvious for the United States, where the tax revolts which started with initiatives, especially proposition 13 in California, induced a political change, but it holds for Switzerland as well. And as the following two examples show, such an effect can take place even if the initiative is officially not successful, i.e. if it is rejected by a majority of voters.

\footnotetext{
${ }^{8}$ See, for example, Feld and Savioz (1997) or Freitag und Vatter (2000) for Switzerland as well as Blomberg et al. (2004) for the United States.

9 For a formal analysis of the stability of the Swiss political system see Moser (1996, 1996a).

10 See, for example, Pommerehne (1978) and Gerber (1996, 1999).

11 See for this Eichenberger (1999).
} 
(i) Despite (or even because of) its direct democratic system Switzerland, had in the recent decades (and still has somewhat) a reputation for being a forerunner in environmental policy. Already on February 18, 1979, Swiss citizens were able to vote about phasing out of nuclear energy. The corresponding initiative was rejected by the people with only a small margin, but it induced a public discourse on the risks of atomic energy which took place much later (if at all) in other European countries like Germany, Austria or France. Because at that time all major parties and interest groups were still in favour of this energy source, there was, for example, no corresponding discourse in Germany.

(ii) On November 26, 1989, people decided whether the Swiss army should be abolished. Before the decision there was an intense and sometimes rather heated public discussion. It is well known that the Swiss army is (or was at least at that time) a 'sacred cow'. Besides the Social Democrats and the trade unions, who both did not give any recommendation, all relevant political parties and interest groups as well as both chambers of the national parliament recommended that this initiative should be rejected. Given this closed position of the whole political establishment and given the traditional commitment of the Swiss population to their army, it was generally expected that only a very small part of the electorate would vote for the initiative; even a $10 \%$ approval seemed to be high. The result was, however, quite different: $35.6 \%$ voted for the abolition of the army, and the turnout of $69.2 \%$ was exceptionally high. This unexpected result changed the political situation and, soon after the referendum, alleviations for those who deny the service in the army have been introduced, like an alternative civilian service.

These two examples show that a direct democratic political system can better take up impulses from outside the political system than a purely parliamentary system. At the Swiss federal level, only the signatures of about $2 \%$ of the electorate are necessary to start an initiative. Thus, people who do not belong to the 'classe politique' have a relatively cheap but official way to bring their interest into the political discourse. The same is much more difficult in a purely parliamentary system, as, firstly, citizens' groups have to be organised, and secondly, these groups have to convince parties to take up their ideas (or even have to found new parties). And as the second example shows, an initiative might be successful in changing politics even in a situation where a priori chances for such a change seem to be rather small.

There is, however, evidence that the retarding effect of the referendum mighton average - be stronger than the accelerating effect of the initiative. The reason for this is that it is easier to mobilise against an issue than in favour of it. Considering the period between 1981 and 1999, Kirchgässner and Schulz (2005) as well as Kirchgässner (2007) showed that mobilisation expenditure against a proposition are about twice as effective than those in favour of the decision: One Swiss Franc spent in a campaign for No-votes has about the double effect compared with a Franc spent in the Yes-campaign. This is in line with earlier results for Switzerland and the United States according to which financially strong interest groups can rather 
prevent the acceptance of a proposal by the citizens than get their own proposals approved. $^{12}$

\section{The role of interest groups and distributional coalitions}

As the statements above show, the leeway which direct democracy provides interest groups is seen as the main reason for the lack of reforms: firstly, the threat of a referendum gives even small interest groups the possibility to gain influence in the legislative process, and secondly, if they are not successful in a first round, they can actually start a referendum in order to prevent the proposed law to come into effect.

The question is, however, whether interest groups are really more successful in a (semi-) direct democracy than in a purely parliamentary system. Their major impact on the legislative process is probably neither the impact they have on the public discussion when a law is in the legislative procedure nor the impact they have on the voters' decisions, but their hardly visible and non-transparent influences first on the bureaucracy in the pre-parliamentary stage and second in the parliamentary committees where representatives of these interest groups can directly influence the new law. This influence might be restricted if the final decision might be at the polls. Thus, the stronger impact interest groups have on the direct-democratic political process via influencing the popular vote might at least partly be outweighed by the restricted impact in the pre-parliamentary and parliamentary stages of the legislative process. The fact, that the impact of interest groups is more open and more visible does not imply that it is really larger. Somewhat simplified: It might be easier (and cheaper) to buy the votes of the majority of the parliamentarians (or even only of the responsible parliamentary committee) than those of a majority of voters.

There are examples where the voters decided against the recommendations of many important (and financially strong) interest groups. Some of the examples mentioned above, like the decisions about joining the EEA in 1992 or about the tax reform in 2004 belong to this group. But there are also examples where the people voted in a referendum or even in an initiative in favour of a proposal despite the fact that influential interest groups spent a lot of money to prevent this. The most prominent example might be the acceptance of the Alpine Initiative (Alpeninitiative) in February 1994 against the recommendations of the vast majority of political parties and interest groups. This also holds, for example, for the introduction of a special charge on commercial traffic (Leistungsabhängige Schwerverkehrsabgabe (LSVA)) in September 1998 which was opposed not only by the association of lorry owners but also by the Swiss Peoples Party, which today is-measured by the votes to the Lower Chamber, the 'Nationalrat' - the strongest Swiss party. This right-wing party, together with its associated civil movement, the 'Campaign for an Independent and Neutral Switzerland' (Aktion für eine unabhängige und neutrale Schweiz, AUNS) organised quite a lot of referenda in the last 15 years, and won

12 See, for example, Hertig (1982), Gruner and Hertig (1983) as well as Longchamp (1991) for Switzerland, or Gerber (1999) for the United States. For a survey of other studies see Kirchgässner et al. (1999, pp. 27ff). 
some, but lost most of them, important as well as less important ones. Thus, despite the empirical evidence mentioned above, it is not as easy to defeat a bill as is often assumed.

Whether Swiss interest groups are more or less influential than those in other countries, is finally an open empirical question. At the moment, there is no study available which allows an answer, and it is far from obvious how their impact could be measured in an international comparable way, to give a definite answer on this question. Nevertheless, Borner et al. (1994, pp. 26f) argue that the threat of a referendum gives even small interest groups particular possibilities for rent-seeking activities. The available indirect empirical evidence is, however, not in line with this supposition. With respect to economic freedom, in 2007 Switzerland had rank nine of the 161 countries considered, together with New Zealand, the United Kingdom and the United States and with a rating of 79.1. ${ }^{13}$ Thus, at least compared to other countries, there does not seem to be a major negative impact of Swiss politics on the economic system. Moreover, in an international comparative study, Katz and Rosenberg (1989) ask for the social waste caused by rent-seeking. They conclude that Switzerland has the smallest waste of all 20 countries considered, it is only $0.19 \%$ of GNP. Even if there has been some criticism of this study, the available evidence does at least not suggest that the waste from rent-seeking is particularly high in Switzerland. ${ }^{14}$

This is, of course, not surprising. Following Olson (1982), the sclerosis (and, correspondingly, the reform-delay) of democratic nations results from the rentseeking activities of 'distributional coalitions' of interest groups. Their influence goes via the parliamentary process. Every single group is too small to get a majority in the parliament, but by combining the votes of many groups, i.e. by logrolling, this might be possible. This kind of 'pork-barrel politics' is possible due to the effect of fiscal illusion: the benefits are concentrated, while the costs of every single measure are so dispersed that they are hardly noticeable for the single voter. Thus, voters support their local candidates and/or the candidates of their parties, if those are active in helping to promote their special (geographic or group) interests. The whole situation is the one of a social dilemma: All voters would be better off if none of these special interests would be satisfied, but it is even better for them if their own special interests are satisfied but not the other ones. Thus, from behaviour which is rational from an individual point of view a socially suboptimal outcome emerges.

The strength of these interest groups increases the longer a stable democratic system exists. Switzerland, a stable democracy since 1848, should, therefore, have very strong distributional coalitions. Such logrolling is, however, extremely difficult in a direct democracy. Firstly and most importantly, binding contracts which can be agreed among parliamentarians are impossible among (many) citizens. Thus, the only way for logrolling contracts are package-deals. This severely restricts the extent of logrolling. Secondly, as mentioned above, Swiss voters are extremely sceptical with respect to package-deals; they usually reject them, even if they would

\footnotetext{
13 See http://www.heritage.org/index/countries.cfm (19/10/07).

14 See the discussion between Schnytzer (1994) and Katz and Rosenberg (1994). For a similar conclusion with respect to the United States see Matsusaka (2004, p. 3).
} 
accept some (or perhaps all) of their elements. Finally, with respect to pork-barrel politics, it is hardly possible to get a majority of the single elements of the packagedeals, just because the benefits are concentrated. Thus, logrolling is much more difficult in a direct democracy than in a purely representative system. Correspondingly, the waste from rent-seeking activities should also be smaller.

As far as reforms are necessary to counteract the results of rent-seeking activities of small interest groups, such reforms should, therefore, be less necessary in a direct democracy. An example might be the fact that the Swiss labour market is much less regulated than the ones of its neighbouring countries. Consequently, deregulation of the labour market is much less a topic in Switzerland than, for example, in Germany or France. ${ }^{15}$ But having - ceteris paribus-less need for reforms does not imply that reforms, once they are necessary, are also easier to put through. The fact that it is easier to mobilise against a change than in favour of it speaks for the opposite. Thus, interest groups might be especially strong in a direct democracy to defend their special privileges.

In defending their privileges, they can be, however, also very strong in a purely representative system. In order not to lose the next election, democratic governments sometimes satisfy the demands even of small interest groups (or parts of the population). The best example of this are the farmers. ${ }^{16}$ They are rather strong in Switzerland, despite the fact that with less than $4 \%$ of the labour force they are today only a very small part of the population. They are, however, also very powerful in France or the United States, which — at the federal level—do not have direct political rights comparable to Switzerland. ${ }^{17}$ Thus, that some even small interest groups are rather influential is not specific to the Swiss political system; it is rather a general phenomenon.

\section{Concluding remarks}

Given the empirical evidence, it would be naive to deny that, due to the referendum, the Swiss direct democracy has a build-in status quo bias. The accelerating effect of the initiative can counteract this to some extent, but it cannot balance it totally. This holds even if it is taken into account that the impact of interest groups in the Swiss political system is hardly larger, probably even smaller, than in other democratic political system. This conservative bias certainly makes sense if basic, constitutional political decisions are considered. Probably all democratic societies have safeguards against easy changes of their constitution; usually a two-third majority (in federal countries of both houses) is demanded. Contrary to this, the Swiss constitution can easily be changed, demanding only a majority of the people and the cantons. And it is, indeed, changed quite often. It is less clear whether this

\footnotetext{
15 Nevertheless, as mentioned above, some deregulation took place with the revision of the labour law that has been accepted in 1998.

16 Another example is the strong impact the National Rifle Association has on US politics. Its influence in the current US system is probably much larger than it would be in a system with referenda and initiatives. See for this, for example, Kirchgässner et al. (1999, p. 31).

17 France does not even have direct popular rights at the lower governmental levels.
} 
bias makes sense with respect to statutory laws. One might argue that with respect to such decisions the new proposal should-ex ante-have equal chances as the status quo.

From a democratic point of view, the question should, however, not be whether new proposals have equal chances as the status quo, but which system does lead to solutions that are closer to the preferences of the citizens (or of the median voter, respectively). In this respect the evidence is clear: the direct democratic system has a clear advantage. Thus, even if there were a reform-delay in comparison to other democratic political systems, from the point of the theory of democracy, these might be costs which have to be borne to come closer to the citizens' preferences. But considering the economic performance, it is far from clear that these are-on average - really costs. The available empirical literature tells us rather the opposite. But as this evidence-necessarily—relates to sub-federal levels, US states or Swiss cantons, it remains open how far this also relates to the federal level. There are good arguments in favour of this position, but one can also question it. ${ }^{18}$

But what would happen if Switzerland were to abolish its direct democracy, at least at the federal level? Given the political status quo, this would lead to quite different political decisions. Not only would all the decisions mentioned in Sect. 2 have been accepted; without the threat of a referendum the pendulum would, with respect to economic decisions, swing to the right but with respect to others possibly to the left: We would have a more liberalised electricity market, for example, and also more liberal naturalisation laws.

But this is only part of the story. As our neighbouring representative democracies show, we would probably have much more regulation, and we might have severe difficulties in deregulating. Moreover, it is naive to assume that the political status quo would last forever. The bourgeois politicians and firm leaders who want to restrict direct popular rights might find themselves in opposition to a left-wing dominated government and a corresponding parliament after some time, and this might even be less in favour of the reforms they demand than today's parliament. Political competition in a purely representative system demands changes of the ruling parties from time to time. Consequently, people favouring economic liberalism (and complaining about a reform-delay) might be faced with a situation which is much less in favour of their interests than the current one. Thus, it is totally open whether an abolition of direct democratic rights at the federal level would really make Switzerland more open to reforms.

This is, of course, pure speculation. The Swiss population will hardly ever accept such a change of their political system, definitely not today and not in the near and medium-run future. Thus, we have to live with the current situation. And this is not as bad as some people want us to believe. While some reforms have been blocked, there have been even some major reforms in Switzerland in recent years, and there are others to come. As Weber (1919, p. 251f) told us, politics is the drilling of thick boards. The boards might be a little bit thicker in a direct democracy, but there might also be fewer holes necessary to be drilled. Those who complain about

\footnotetext{
18 See, for this discussion Kirchgässner et al. (1999, pp. 105ff). This position is questioned, for example, by Wittmann (2001, pp. 31f).
} 
missing reforms in the Swiss democracy are at least sometimes citizens who are convinced that their special interests would be better served in a system which did not allow the other citizens to prevent this. ${ }^{19}$ But this would not necessarily be an advantage for the whole Swiss society.

\section{References}

Borner, S., Brunetti, A., \& Straubhaar, T. (1990). Schweiz AG: Vom Sonderfall zum Sanierungsfall? Verlag Neue Zürcher Zeitung, Zürich.

Borner, S., Brunetti, A., \& Straubhaar, T. (1994). Die Schweiz im Alleingang. Verlag Neue Zürcher Zeitung, Zürich.

Blomberg, S.B., Hess, G.D., \& Weerapana, A. (2004). The impact of voter initiatives on economic activity. European Journal of Political Economy, 20, 207-226.

Eichenberger, R. (1999). Mit direkter Demokratie zu besserer Wirtschafts- und Finanzpolitik: Theorie und Empirie. In H.H. von Arnim (Ed.), Adäquate Institutionen Voraussetzung für ,gute” und bürgernahe Politik? (pp. 259-288). Duncker und Humblot, Berlin.

Feld, L. P., \& Savioz, M. R. (1997). Direct democracy matters for economic performance: An empirical investigation. Kyklos, 50, 507-538.

Fernandez, R., \& Rodrik, D. (1991). Resistance to reform: Status Quo Bias in the presence of individualspecific uncertainty. American Economic Review, 81, 1146-1155.

Freitag, M., \& Vatter, A. (2000). Direkte Demokratie, Konkordanz und Wirtschaftsleistung: Ein Vergleich der Schweizer Kantone. Schweizerische Zeitschrift für Volkswirtschaft und Statistik 136, 579-606.

Gagales, A., Braumann, B., \& Polan, M. (2005). Selected issues. IMF Country Report No. 05/188. Switzerland.

Gerber, E. R. (1996). Legislatures, initiatives, and representation: The effects of state legislative institutions on policy. Political Research Quarterly, 49, 263-286.

Gerber, E. R. (1999). The populist paradox: interest group influence and the promise of direct legislation. Princeton University Press, Princeton.

Germann, R. E. (1975). Politische Innovation und Verfassungsreform. Haupt, Bern.

Gruner, E., \& Hertig, H. P. (1983). Der Stimmbürger und die 'neue' Politik. Haupt, Bern.

Hertig, H. P. (1982). Sind Abstimmungen käuflich? Schweizerisches Jahrbuch für Politische Wissenschaft, 22, 35-58.

Imboden, M. (1964). Helvetisches Malaise. EVZ-Verlag, Zürich.

Katz, E., \& Rosenberg, J. (1989). Rent-seeking for budgetary allocation: preliminary results for 20 countries. Public Choice, 60, 133-144.

Katz, E., \& Rosenberg, J. (1994). Support in the guise of criticism: extraneous observations and the KatzRosenberg measure of rent-seeking. Public Choice, 79, 363-366.

Kirchgässner, G. (2007). The status quo bias in direct democracy: Empirical results for Switzerland, 1981-1999, paper presented at the World Meeting of the Public Choice Societies, Amsterdam, March 30, 2007.

Kirchgässner, G., \& Schulz, T. (2005). Was treibt die Stimmbürger an die Urne? Eine empirische Untersuchung der Abstimmungsbeteiligung in der Schweiz, 1981-1999. Swiss Political Science Review, 11, 1-56.

Kirchgässner, G., Feld, L. P., \& Savioz, M. R., (1999). Die direkte Demokratie: Modern, erfolgreich, entwicklungs- und exportfähig, Helbing und Lichtenhahn/Vahlen, Basel/München.

Longchamp, C. (1991). Herausgeforderte demokratische Öffentlichkeit: Zu den Möglichkeiten und Grenzen des politischen Marketings bei Abstimmungen und Wahlen in der Schweiz. Schweizerisches Jahrbuch für Politische Wissenschaft, 31, 303-326.

Moser, P. (1996). Why is Swiss politics So Stable? Schweizerische Zeitschrift für Volkswirtschaft und Statistik, 132, 31-60.

${ }^{19}$ See, for example, Kirchgässner et al. (1999, pp. 173ff). 
Moser, P. (1996a) Zwischen Immobilität und Instabilität: Auswirkungen der Einführung der allgemeinen Volksinitiative und der Verfassungsgerichtsbarkeit in der Schweiz, Schweizerische Zeitschrift für Politische Wissenschaft, 2, 233-255.

Matsusaka, J. G. (2004). For the many or the few: the initiative, public policy, and American democracy. University of Chicago Press, Chicago.

Olson, M. (1982). The rise and decline of nations: economic growth, stagflation, and social rigidities. Yale University Press, New Haven/London.

Pommerehne, W. W. (1978). Institutional approaches to public expenditure: empirical evidence from Swiss municipalities. Journal of Public Economics, 9, 255-280.

Samuelson, W., \& Zeckhauser, R. (1988). Status Quo Bias in decision making. Journal of Risk and Uncertainty, 1, 7-59.

Scharpf, F. W. (1988). The joint decision trap: lessons from german federalism and European integration. Public Administration, 66, 239-278.

Schnytzer, A. (1994). Changes in budgetary allocations and international comparisons of the social cost of rent-seeking: a critical note. Public Choice, 79, 357-362.

Weber, M., (1919). Politik als Beruf, Duncker und Humblot, Berlin 1919. In H. Baier et al. (Eds.), Max Weber Gesamtausgabe, Band 17 (pp. 165-252). Mohr (Siebeck), Tübingen 1992; English translation: The profession and vocation of politics. In M. Weber, Political writings (pp. 309-369). Cambridge University Press, Cambridge (England) 1994.

Wittmann, W. (1998). Die Schweiz: Ende eines Mythos. Wirtschaftsverlag Langen Müller/Herbig, München.

Wittmann, W. (2001). Direkte Demokratie: Bremsklotz der Revitalisierung, Huber, Frauenfeld et al. 